\title{
NATIONAL LAW DEVELOPMENT IN NEW NORMAL ERA
}

\author{
Benny Riyanto \\ National Law Development Agency \\ Ministry of Law and Human Rights Republic of Indonesia \\ E-mail: dr.bennyriyanto@yahoo.com
}

\begin{abstract}
According to legal perspective, the Government's plan to implement New Normal desires to restore economic life and public health as a manifestation of the fulfillment of citizens' rights. From the description above, this paper will discuss several things, namely how the readiness of national Law to welcome the new normal era; how the constitutional legal system in the new era is normal; how is the urgency of structuring national regulations in the new normal era; and, how the influence of the new normal era for legal politics and public legal awareness. By using the normative juridical method, it can be concluded that the status of COVID-19 pandemic in Law is marked by the issuance of various legislative products to provide legal certainty of the Government's policy to overcome COVID-19 and implement New Normal policy. The practice of state administration is increasingly being carried out in the executive, legislative, and judiciary environments by utilizing digital networks through application facilities that provide virtual meeting services.
\end{abstract}

Keywords: National Law Development, new normal, restriction, regulation.

\section{A. Introduction}

Large-scale Social Restrictions (PSBB) under Government Regulation number 21 of 2020 aims to prevent the spread of Corona Virus Disease 2019 (COVID-19). It is actually based on Law No. 24 of 2007 on Disaster Management and Law No. 6 of 2018 on Health Care. This government regulation was followed up with the issuance of Regulation of the Minister of Health of the Republic of Indonesia Number 9 of 2020 regarding the Guidelines for Large-Scale Social Restrictions in Accelerating Corona Virus Disease 2019 (CO-
VID-19) Mitigation. Article 13 paragraph (1) specifies the Implementation of LargeScale Social Restrictions which includes:

1. school and workplace;

2. restrictions on religious activities;

3. restrictions on activities in public places or facilities;

4. restrictions on social and cultural activities;

5. restrictions on modes of transportation; and

6. restrictions on other activities related explicitly to defense and security aspects. 
Article 13 paragraph (3) excludes offices or strategic institutions providing services related to defense and security, public order, food needs, oil and gas fuels, and health services as regulated in paragraph (1) letter (a). Achmad Yurianto, as the government spokesperson, revealed that PSBB carries many functions, such as preventing the gathering of people, both in small numbers and large numbers, and suppressing the spread of the corona virus within the community. ${ }^{1}$

The imposition of PSBB is exptected to protect people from the transmission of COVID-19. However, of course, there is no successful policy unless the people are willing to cooperate. Nevertheless, not all people support this policy. Entrepreneurs consider PSBB has caused several industries to fall into a coma. Moreover, many sectors have to face weakening demand since the coronavirus pandemic. The worst affected sectors were tourism, transportation services, events, and property. $^{2}$

The Ministry of Manpower as of 20 April 2020 noted that 2.2 million workers had been fired and laid off, this figure would continue to grow until the pandemic was over. Thousands of companies will also be out of business if the pandemic does not end in three months. The number of poor people is even predicted to increase in the range of 1.1 million to 3.78 million people. ${ }^{3}$ As a result of this pandemic, crime is also rife, and the numbers are predicted to continue rising.

Not only in the economic sector, but this pandemic also causes social impact. Many workers who were laid off did not even get severance pay due to this outbreak. Their income had to stop while they still have everyday needs to fullill. Moreover, day laborers who live in big cities, can no longer survive and must return to their hometowns to live on. Thus, an elevated unemployment rate can also have the potential to increase social conflicts such as crime. ${ }^{4}$

The number of COVID-19 casualties has continued to rise since the implementation of PSBB. This implementation also has impacted the economic and social conditions. Moreover, WHO has also stated that the corona virus, for the time being, cannot be eliminated from all aspects of life. ${ }^{5}$ This was also confirmed by the statement of President Joko Widodo saying that "Later on the society must make peace and coexist with COVID-19 because the virus will not disappear, and co-existing does not mean we are

1 accessed from https://idcloudhost.com/ menelusuri-dampak-yang-ditimbulkan-psbb-di-seluruh-wilayah-indonesia, "Tracing the Impact of PSBB in All Regions of Indonesia ", 2 June 2020

2 accessed from, https://www.kiostix.com/id/article/503/dampak-penerapan-psbb-dan-tujuan-mulianya, "Impact of PSBB Implementation and Its Original Purpose" 3 June 2020

3 Ayomi Amindoni, The wave of layoffs in the midst of the COVID-19 pandemic is estimated to reach its peak in June, the Pre-employment Card is considered ineffective, accessed from https://www.bbc.com/indonesia/indonesia-52218475.

4 Hana Faiya Fikriyyah, "PSBB, Economic Impacts to Social Impacts", accessed from https: //www.kompasiana. com/hanafaiha/ 5eba5782097f3667e34daa62/psbb-dampak-ekonomi-hingga-dampak-sosial.

5 Farras Fadhilsyah, " New Normal in a Political Perspective", accessed from Suara.Com., 02 June 2020. 
giving up, but we are adapting. We fight COVID-19 by prioritizing and requiring strict health protocols". ${ }^{6}$

From the above background, the Government is currently trying to loosen PSBB by applying a "New Normal" policy that might be considered to be more lenient in anticipating the impact of COVID-19 in Indonesia. Proven by observing the readiness to implement new normal health protocols in public facilities in Bekasi City, President wanted to ensure that Indonesian people understand and must immediately prepare for a new rules for the new normal carried out by President Joko Widodo. ${ }^{7}$

The term "New Normal or Normal Baru" was first used by Roger McNamee, "a technology investor," who reviewed in an article by Polly LaBarre entitled "The New Normal" in Fast Company magazine on 30 April 2003. In his writing, Roger McNamee interpretes new normal as a time where one is most likely willing to play with new rules for the long term. In New Normal or Normal Baru, it is more important to do things right than to give in to the tyranny of urgency. Meanwhile, according to Wikipedia, New Normal is a term in business and economy that refers to financial conditions after the 2007-2008 financial crisis and after the 2008-2012 global recession. This term emerged from the context of reminding economists and policymakers that the industrial economy will return to their latest ways after the 2007-2008 financial crisis. The term New Normal has since been used in a variety of other contexts to imply that something that was previously abnormal has become commonplace. ${ }^{8}$

Linguistically, according to linguist Rahayu Surtiati Hidayat from the University of Indonesia, a new normal is the new normality. ${ }^{9}$ It is a change in behavior by always applying health protocols in all aspects of life/activities such as physical distancing, wearing masks, having handwashing facilities, and following the etiquette of coughing and sneezing.

Furthermore, according to Psychologist Yuli Budirahayu, it is a change in behavior to continue to carry out normal activities but by implementing health protocols to prevent COVID-19 transmission such as using mask when leaving the house and always washing hands with soap. ${ }^{10}$ While the Team Leader of the Expert Team for

6 accessed from Https://www.tribunnews/com/corona/2020/05/26/ pengertian-new-normal-dan-protokolpencegahan-penularab-COVID-19-di-tempat-kerja,. "Understanding of the New Normal and COVID-19 Transmission Prevention Protocol in the Workplace",02 June 2020.

7 Zaki Fahminanda, "New Normal" accessed from https://www.kompasiana.com/ zakifahmi/5ecfea79d541df3e3 41380f2/simalakama-new-normal?page=all\#sectionall.

8 accessed from https://www.kompasiana.com/hpinstitute/ 5ead17b5d541df3e62051864/ memahami-istilahnew-normal,. "Understanding the Term" New Normal" 02 June 2020.

9 https://news.detik.com/berita/d-5034719/ tentang-new-normal-di-indonesia-arti-fakta-dan-kesiapan-daerah, diakses pada tanggal 2 Juni 2020.

10 accessed from Https://www.tribunnews/com/corona/2020/05/26/ pengertian-new-normal-dan- protokolpencegahan-penularab- COVID-19-di-tempat-kerja,. "Definition of New Normal and Protocol to Prevent COVID-19 Transmission in the Workplace"02 June 2020 
the acceleration of COVID-19 mitigation, Wiku Adisasmita, states that new normal is a change in behavior to continue carrying out normal activities, but by implementing health protocols to prevent transmission of the COVID-19 virus. ${ }^{11}$

The University of Indonesia (UI) epidemiology expert Pandu Riono said, new normal places more emphasis on individual readiness for activities outside the home even though the SARS-CoV-2 coronavirus - the cause of COVID-19 has not disappeared. New normal is the new behavior of the community when the activities are running as usual. Public spaces such as offices, schools, industries, and malls will open again. However, the most important of these is how we behave when we are in public spaces. Every policymaker from various sectors must implement standards and conditions to abide when starting to open services. These standards and conditions must still follow the COVID-19 transmission prevention protocol. New normal is a way to regulate the behavior of the population, either the community, business people, Government, or various other sectors in order to reduce the risk of the possibility of transmission of COVID-19, because the SARS-CoV-2 coronavirus still exists. ${ }^{12}$

The implementation of New Normal should be based on thorough consideration to keep minimizing the spread of COVID-19. The Task Force for handling Corona Virus in Indonesia has established 3 (three) indicators for the implementation of New Normal, namely: ${ }^{13}$

1. The epidemiological aspect which is related to Corona case data in the field. Each region can impose New Normal when the graph or Corona case curve has decreased by 50 percent. However, the decline cannot be only one or two days but must have been occured for two weeks from the last peak. In addition, the number of people in monitoring (ODP), patients under surveillance (PDP) should also have decreased, including cases of death. And conversely, the number of cured patients must have increased;

2. Aspects of public health surveillance. The surveillance here refers to an active response of the local Government to carry out massive Corona tracking;

3. Health Service Aspects. All health services in the area must have complete facilities for handling COVID-19 patients.

Furthermore, based on data from the Presidential Secretariat there are 4 provinces and 25 districts / cities, which are ready to implement New Normal, including: ${ }^{14} 4$ (four) Provinces, namely: DKI Jakarta, West Sumatra, West Java,

11 accessed from www.Instagram.com/p/CasGWejHW3b/?gshid=1fnba8c5oavgr-bicarapolitikhukum 1-6-2020.

12 accessed from "New Normal Is Not Just Opening Public Space, Says Experts", https://www.kompas.com/ sains/ read/2020/05/29/110000923/new-normal-bukan-sekadar-membuka-ruang-publik-begini-kata-ahli 3 june 2020.

13 accessed from TribunWow.com and Youtube KompasTV, Rabu (27/5/2020)5.

14 accessed from https://www.liputan6. com/news/read/4263884/ini-4-provinsi-dan-25-kabupatenkota-yang- 
and Gorontalo; and 25 (twenty five) Regencies / cities namely: Pekanbaru City, Dumai City, Kampar Regency, Pelalawan Regency, Siak Regency, Bengkalis Regency, Palembang City, Prabumulih City, Tangerang City, South Tangerang City, Tangerang Regency, Tegal City, Kota Surabaya, Malang City, Batu City, Sidoharjo Regency, Gresik Regency, Malang Regency, Palangkaraya City, Tarakan City, Banjarmasin City, Banjar Baru City, Banjar Regency, Barito Kuala Regency, Buol Regency.

The Government's plan to implement New Normal is intended to restore economic life and public health which according to the legal perspective is the manifestation of the fulfillment of the rights of citizens as follows:

1. The Rights to have an occupation and have a proper living for a human being (Article 27 paragraph 2 of the 1945 Constitution of the Republic of Indonesia)

2. The Rights to live and to defend life and existence (Article $28(\mathrm{~A})$ of the 1945 Constitution of the Republic of Indonesia);

3. The right to obtain health services (Article $28(\mathrm{H})$ paragraph 1 of the 1945 Constitution of the Republic of Indonesia);
4. The Rights to get facilities and specialized treatment to obtain equal opportunities and benefits in order to achieve equality and justice (Article 28(H) paragraph 2 of the 1945 Constitution of the Republic of Indonesia).

Imposing New Normal policy in a province or district/city must be accompanied by monitoring and evaluation of the implementation of $\mathrm{New}$ Normal. Apart from that, it is also requires the participation of all levels of society to comply with the health protocols as a new social order.

From the description above, this paper will discuss several things, namely: 1) how the readiness of national law to welcome the new normal era; 2) how the constitutional legal system in the new normal era; 3 ) how is the urgency of structuring national regulations in the new normal era; and, 4) how the influence of the new normal era for legal politics and public legal awareness.

\section{B. Research Method}

Based on the problems and background above, this research was conducted using a normative juridical approach. ${ }^{15}$ As a normative juridical study, this research was based on an analysis of legal norms, both law in the sense of written law as

akan-terapkan-new-normal : "These 4 Provinces and 25 Regencies / Cities Will Apply New Normal."

15 Normative research is research conducted by examining mere library materials or secondary data. Normative thinking is based on research that includes (1) legal principles, (2) systematic law, (3) vertical and horizontal synchronization levels, (4) comparative law, (5) legal history. More about this see Soerjono Soekanto dan Sri Mamudji, Role and Use of Libraries in Legal Research, (Jakarta: Pusat Dokumentasi Hukum Fakultas Hukum Universitas Indonesia, 1979) p.15. 
it is written in the books and statutes (in literature and legislation). ${ }^{16}$ References were also obtained from other related documents such as the results of previous studies, seminars and workshops, books, and related scientific journals, as well as data from various media, both print and electronic. The research tradition using mass media reports, especially newspapers and the internet, has proliferated over the past few decades, especially in the field of collective action studies and social movements.

\section{Discussions}

\section{National Legal Readiness towards The New Normal Era}

The issuance of Presidential Decree No. 11 of 2020 concerning Declaration of COVID-19 as Public Health Emergency signified the status of the Corona Virus Disease 2019 as pandemic (COVID-19) in Indonesia, which was further strengthened by Presidential Decree No. 12 of 2020 concerning Determination of Non-Natural Disaster Spread of Corona Virus Disease 2019 (COVID-19) as a National Disaster. Therefore, it can be categorized as a cause of force majeure in contracts in general. Furthermore, in order to protect the economy, the Government has issued Government Regulation in Lieu of Law Number 1 of 2020 regarding State Financial Policy and Financial System Stability for Handling Corona Virus Disease 2019 (COVID-19) and/or in order to ManageThreats Harming National
Economy and/or Stability Financial system.

The Government of Indonesia, after the announcement of first confirmed case of COVID-19 virus on 2 March 2020, continues to increase efforts to reduce the spread of COVID-19, ranging from limiting social relations (social distancing), limiting physical contact (physical distancing) to instructing all state apparatus, employess of State-Owned Enterprises (BUMN) and private employees to restrict activities in the office by encouraging work from home. The Government also issued a policy to make peace with COVID-19 by echoing the New Normal or new lifestyle that cannot be separated from the efforts that have been made in dealing with the spread of COVID-19.

The enactment of health protocols with restrictions on community movements carried out by the Government has a direct impact on the community including the public service sector providing direct services to the public, health services at various levels of health facilities, lease services in the banking services sector and so forth. Based on the results of the Survey on the Mal-administration Perceptions of the Republic of Indonesia (Inperma) conducted by the Indonesian Ombudsman in $2019,70.3 \%$ of respondents prefer direct interaction administration to online mechanisms or using intermediary services. The restrictions imposed by the Government have hindered the provision of services. ${ }^{17}$

This condition caused by the 
tendency of the Indonesian people who predominantly prefer to access public services directly, not to mention the supporting infrastructure for online-based public services is not optimal both in terms of state organizers and the socialization of the public to access public services online.

According to Article 1 paragraph (1) Law Number 25 of 2009 on Public Services, "public services are activities or series of activities in the framework of meeting service needs following statutory regulations for each citizen and population of goods, services, and/or administrative services provided by public service providers." Article 21 specifies 14 components that each public service provider must fulfill :

a. legal basis, statutory regulations which are the basis of service delivery;

b. requirements, requirements to comply in maintaining services, both technical and administrative requirements;

c. systems, mechanisms, and procedures, standardized service procedures for service providers and users, including complaints;

d. completion period, the time needed to complete the entire service process for each type of service;

e. fees/tariffs, fees charged to the service recipient in managing and/or obtaining services from the organizer whose amount is determined based on an agreement between the organizer and the community;

f. service outputs, the results of services provided and received under the established conditions;

g. facilities, infrastructure, and/or facilities, equipment and facilities needed in the delivery of services, including equipment and facilities for vulnerable groups;

h. competencies of implementer, abilities that must be possessed by implementers consisting of knowledge, expertise, skills, and experience;

i. internal supervision, control carried out by the head of the work unit or the direct supervisor of the executor;

j. complaints, suggestions, and input handling, procedures for handling complaints and their follow-up;

k. number of implementers, availability of executors according to workload;

I. service guarantees that provide certainty of services carried out in accordance with service standards;

m. guarantee the security and safety of services in the form of a commitment to provide a sense of security, free from danger and risk of doubt; and

$n$. evaluating the performance of implementers, evaluating to find out how far the implementation of activities is according to service standards.

The State, as a public servant, sets a new normal policy and the implementation of health protocols which cause the restriction of access to public services. This policy is an effort of the State to administer public services in order to maximize public services delivery. 


\section{The Practice of National Law System in The New Normal Era}

Currently, the public is familiar with the executives, legislatives, and judiciaries utilizing digital networks in virtual meeting. The cabinet meetings held by the President and the ministers since the COVID-19 outbreak have always used digital facilities. Even though the President and his ministers are physically far apart, they manage to produce many agreements and decisions on strategic policies concerning the lives of many people by means of virtual meetings. Such effort is consistent with the mandate of Presidential Decree No. 1 of 2020 concerning State Financial Policy and Financial System Stability for Handling the COVID Pandemic-2019, Government Regulation No. 21 of 2020 concerning Large-Scale Social Restrictions (PSBB) and Presidential Decree No. 11 of 2020 concerning Declaration of the Public Health Emergency of COVID-19 as Public Health Emergency.

Similar situation also takes place in the House of Representatives (DPR). Despite having an extended recess period for up to a week, DPR finally held the opening of plenary meetings at the end of March. Meetings of the Complementary Organs of the House of Representative (AKD)combine face-to-face meetings and virtual meetings (hyrbid). The quorum requirement, which under normal circumstances become an absolute requirement, is changing under the current situation.

Meetings held by the House of Representatives hold the health protocols principles by maintaining physical distancing. And several important decisions have been delivered from this hybrid mechanism. For example, the decision to terminate the National Examination (UN) in 2020, as well as an agreement with the DPR, the Government, and the General Elections Commission (KPU) to postpone the implementation of the Simultaneous Regional Election on 23 September 2020.

Judicial institutions have also taken the same practices. Circular of the Supreme Court No. 1 of 2020, encourages the seekers of justice to make the most of e-court applications for administration proceedings and e-litigation for trials, especially for cases of civil, religious and administrative (TUN). COVID-19 has forced the branches of power to be adaptive to digital environment. Whether realizing it or not, the situation has changed the disruptive perspective of administration. It has changed the pattern and mechanism that once was only an idea. This condition seems to have found the valve in the middle of the euphoria of digitalization, especially around the branches of state power. Even though in reality, there are not many public policies have a digitaldisruptive perspective.

Lessonlearned from the metamorphosis of branches of state power due to the COVID-19 pandemic can be an essential lesson for the State to innovate in a concrete and tangible manner that does not only have a dimension of the structured state mechanism which emphasizes the technical aspects only. However, a digital- 
disruptive perspective in public affairs is needed. Digital disruptive is a condition that occurs due to changes in digital technology and the form of business models in the digital era that can result in ease, speed, clarity, and security of a running business condition. This condition is in line with the 4.0 to 5.0 era that exists today.

The State should have formulated the public policy framework that is digitally adaptable in the public sphere, whether in political, economic, social, and cultural fields, including in the State affairs. Efforts toward that direction has emerged, but is not yet stable and sharp.

Particularly in the state administration, such policies will rise the debureaucratization wave in public sector, transparency that is in line with the aspect of saving state finance. State institutions that have the authority to make public policy should have a digital perspective that is disruptive oriented. As Klaus Scwab (2016) points out, a country will reap economic and financial benefits if it can formulate international norms that are adaptive to the main fields of the new digital economy, including the internet for things. ${ }^{18}$

In addition to these aspects, a digital-disruptive perspective must also target the mechanisms in public policy formulation process. This formula is quite essential, especially in this COVID-19 situation. Room of participation and public involvement need to be expanded. If room of participation has previously been embodied by public hearings (RDPU), seminars, and other similar events, in the future virtual spaces should be able to become a new channel for the public to express their aspirations. Andrzej Kaczmarczky (2010) believes that the existence of digital platform/ the Internet will basically provide higher level of public involvement in the formulation of publicoriented policies. Digital platform can also be an authentic medium for political transformation to avoid media bias (both social media and conventional media). ${ }^{19}$ In that context, Indonesia has unwittingly adopted the digital utilization model as a medium to convey public aspirations.

Moreover, the transformation of state administration has eventually taken place in the past month, from conventional models to digital-based models. State institutions are forced to metamorphose to stay "in motion", which means the State continues to carry out its constitutional function in providing aspects of the protection and fulfillment of the rights of citizens amid this emergency.

In order to implement this new normal, as a rule of Law, the Indonesian Government must be guided by the existing National Law. Indonesia's national

18 Accessed from "Tantangan Bertata Negara di Tengah Disrupsi Sekaligus Era Pandemi COVID-19" Kompas.com 23/04/2020, 13:13 WIB.

19 Accessed from https://nasional.kompas.com/read/2020/04/23/13135641/tantangan-bertata-negara-di-tengah-disrupsi-sekaligus-era-pandemi-COVID-19. 
legal system itself is a law or legislation that is formed and implemented to achieve the goals, foundations, and ground norms of a country. In this context, Indonesian national Law is a legal entity or statutory regulation that is built to achieve the goals of the country, which is based on the Pancasila and the 1945 Constitution of the Republic of Indonesia. Thus, the Indonesian national legal system is a legal system that applies throughout Indonesia, which includes all legal elements ( such as content, structure, culture, facilities, laws and regulations, and all the sub-elements) that are interdependent. ${ }^{20}$ This National Law System forms a unified interrelation between modern legal politics and traditional Law that reflects the communal legal culture based on Pancasila. ${ }^{21}$

National Law must be able to answer problems in undergoing adjustments that need to be done in the new normal era. Changes in behavior in the new normal era are the imposition of obligations to follow the health protocols and certain restrictions in the society. Violations of obligations and prohibition/restrictions may be subject to sanctions because deviations from the Law cannot be justified on the grounds of a COVID-19 pandemic. Law enforcement must continue but it should be adjusted to new normal circumstances because law serves as a tool of social engineering for the interests of the society and must be enforced as a social control in order to achieve the desired changes.

Various behavioral changes such as arrangements related to physical distancing to physical absence, the application of health protocols, and the presence of various restrictions have induced the people to prioritize communication/ digital technology as a bridge between individuals. Physical presence, in various laws and regulations, is mandatory, and this becomes the main problem in the application of new normal. As the new normal being implemented, several behavioral adjustments need to be incorporated in our law.

Article 5 paragraph (1) of Law No. 11 of 2008 concerning Electronic Information and Transactions (ITE) answers the issue concerning the validity of Information Documents and Electronic Signatures in the evidentiary system. In general, it is stated that Electronic Information and/or Electronic Documents and/or the printouts are admissable evidence, which are the extension of admissable evidence under the applicable Procedure Law in Indonesia. Consequently, Electronic Signatures have legal force and legal effect.

Article 5 paragraph (1) to paragraph (3), expressly states that: Electronic Information and/or Electronic Documents and/or the printouts constitute admissable evidence and are the extensions of admissable evidence in accordance with prevailing Procedure Law in Indonesia.

Mahfud MD, Building Legal Politics, Upholding the Constitution, LP3ES, Jakarta, 2006, p. 21.

21 Accessed from https://www.bphn.go.id/data/ documents/ fgd_dphn_prof._romli_a_ konsep_reformasi_sistem hukum_ nasional.pdf, on 02 June 2020. 
However, under paragraph (4) Electronic Information and/or Electronic Documents are excluded the following: letters that must be made in writing according to the law; and b. letters and the documents that must be made by notary deed or deed drawn up by the deed officer.

Based on these exceptions, it can be seen that not all regulations accommodate this new normal situation, as in the Notary position. It has been widely ackowledged that many Notary works use technology. For this reason, a legal framework is needed to prevent Notaries from being ensnared in legal cases in the future. Even as a public official, a notary must be protected by laws.

Several efforts have been taken with the issuance of various implementing regulations of Law to resolve problems emerged during the pandemic. For example, the Financial Services Authority (OJK) has issued five OJK Regulations (POJK) to respond to the issuance of Government Regulation in Lieu of Law (Perppu) No. 1 of 2020 concerning State Financial Policies and Financial System Stability for Handling COVID-19 Pandemics. One of the solutions to legal issues related to physical presence is $\mathrm{POJK}$ Number 16 / POJK.04 / 2020 Concerning the Electronic General Meeting of Shareholders. However, it requires other higher instruments or having an effect equivalent to that of laws to guarantee legal protection and certainty.
It should be understood that the new normal situation should not be used as an excuse to deviate/violate applicable Law. Law shall be enforced, but the enforcement/ criminal sanctions should be harmonized with the new normal condition. In criminal law, for example, fines/imprisonement can be replaced by social works while following the health protocols. Similar practice has been enforced to violators of Large-Scale Social Restrictions (PSBB) who do not wear masks. They are charged to carrying out cleaning tasks and in this case, discretion has been displayed. Behavioral changes in the new normal era are the enforcement of legal system that primarily aims to create peace (justice for peace) within the people in accordance with Pancasila.

\section{The Urgency of The Arrangement of National Regulations in The New Normal Era}

In its implementation, regulations related to Large-Scale Social Restrictions (PSBB) are still overlapping and even counterproductive. Such as Circular of the Minister of Industry No. 7 of 2020 on Guidelines on Filing Business Activity Permist during the Health Emergency of Corova Virus Disease 19 (COVID-19), which contradicts Regulation of Governor of Special Region of Jakarta No. 33 of 2020 concerning Implementation of LargeScale Social Restrictions for Corona Virus Disease 2019 (COVID-19) Mitigation Accessed from https://mediaindonesia.com/read/detail/305730-regulasi-tumpang-tindih-dan-bertentangan-
persulit-penegakan-hukum 1 June 2020. 
in Jakarta. ${ }^{22}$ Similarly, the Ministry of Transportation Regulation allows public transportation to return from outside the area. After previously banning all modes of public transportation to operate, except logistics, the Government then allowed the operation of all modes under certain circumstances. ${ }^{23}$ The data also revealed that of the 10 (ten) provinces with the most positive cases, there were only 3 (three) provinces that implemented PSBB, namely DKI Jakarta, West Java, and West Sumatra, while the rest do not implement PSBB. Therefore, the President said, it was also necessary to evaluate provinces, regencies, and cities that did not carry out PSBB and implemented physical distancing policy and implemented strict health protocols. ${ }^{24}$

Having disharmonized regulations has caused legal uncertainty for the public as well as government officials at the lowest level to control and educate the public to implement the existing regulations. If there are unclear rules, legal observance will never be achieved. Legislation is an important element under the rule of law in the efforts of achieving national goals. Ineffective regulations will have negative influences on the Rule of Law. In this regard, the effectiveness of a Regulatory Agency/Agenciesis needed in regulating and simplifying regulations and legislation so as not not to ensnare and slow down the Government's move to take policies. ${ }^{25}$

The formation of the National Regulatory Body is actually not a new story. The idea of the formation of the National Regulatory Body in Indonesia was raised when Joko Widodo was elected as President for the second time. The purpose of the formation is relatively simple, that is to create a legitimate and a single window for the management and efforts to increase professionalism on the policy of laws and regulations.

Although creating pros and cons among the public, either experts or state administration practitioners, President Joko Widodo is strongly committed to establish a dedicated body to administer and harmonize all laws and regulations. This effort has been reflected by the enactment of Law No. 15 of 2019 on the Amendments to Law No.12 of 2011 on the Formulation of Laws and Regulations but it has not been manifested in a legitimate institution in the second period of the Working Cabinet era.

Nevertheless, it does not mean that the discussion concerning this issue ends. If the Government wants an Agency or Institution that is integrated, solid, and professional to deal with the legislation sector, the rational will be because the existing regulations are not harmonious

\footnotetext{
23 Accessed from https://www.kompas.tv/article/80195/ada-tumpang-tindih-aturan-pemerintah-saat-pandemicorona 2 June 2020.

24 Accessed from https://setneg.go.id/baca/index/pemerintah_evaluasi_pelaksanaan_psbb_secara_menyeluruh 2 June 2020.

25 Accessed from https://www.setneg.go.id/ baca/index/ menata_regulasi_di_pusat_dan_daerah _demi_kecepatan_merespons_perubahan 3 June 2020.
} 
and tend to be over regulation.

Considering Agencies or Institutions with similar duties to harmonize legislation have been existed under the Ministry of Law and Human Rights, which are, the National Legal Development Agency (BPHN) and the Directorate General of Legislation (DG PP), it is deemed necessary to strengthen the legitimacy of these agencies so as to be more 'powerful' to reduce and harmonize the dimension of 'ego-sectoral.'

The urgency of forming a National Regulatory Bodies/Institutions is becoming increasingly important in the context of situations where information and technology exchanges is increasingly fast and unpredictable. The State must be able to adapt to the contingency flow of the times, and think to adjust to all its acceleration.

The urgency of establishing a National Regulatory Body must be based on the underlying desire for the State to 'anticipate' formats desired by the State. The anticipation that can unite the dimensions of calculation, dimensions of preparation, mentality, dimensions of risk, and consequences will be prominent and a defining factor that can save the country from the times of accelerating changes.

The State will not be able to produce exclusive legislation. In contrast, the effects of massive information disclosure and technology have made the exchange of vision, mission, thoughts, and processes of a global phenomenon have spread and intertwined so quickly and inevitably between individuals or among groups of people.

In the future, the National Regulatory Body will potentially be able to detect and minimize the risk for failure of the State administration in the new normal context. In the era of the new normal era, the importance of policy synergy between government institutions, including ministries and ministerial-level agencies, is increasingly apparent in implementing existing provisions while removing sectoral egos. For example, related to restrictions on movement of people and vehicles, from and to the regions implementing PSBB, the Police, the Transportation Office, the Civil Service Police Unit, the Civil Apparatus of Regional Government (Pemda), the National SAR Agency, Indonesian National Armed Forces, Ministry of Health, Fire Fighting Unit, and many more, have been involved.

All institutional policies and institutions must be managed in harmony so that they can go hand in hand. This condition is suitable for the National Regulatory Body to play a strategic role in overseeing the process of forming every existing policy in order to support the new normal policy within the framework of the national legal system.

Constitutionally and administratively, sooner or later the Indonesian Government needs an institution or agency that is dedicated to regulate and manage the laws and regulations from the chaotic context of the current legislation - as if competing each institutions vigorously issue any laws 
and regulations to serve their own interests (ego sectoral and hyper-regulation).

\section{The Influence of The New Normal Era to Legal Politics And Public Legal Awareness}

Every policy taken by the Government in a Country will undoubtedly have its consequences. These policies are a form of State interference in all aspects of the lives of citizens, which also constitute State obligations. As a Rule of Law as stipulated under Article 1 paragraph (3) of the Constitution of the Republic of Indonesia, Indonesia is a rule of Law country, of which one of the goals of the State of Indonesia is to advance general welfare ${ }^{26}$, which refers to welfare for the people.

In the implementation of national law development, there are 2 (two) fundamental foundations as the pillars. ${ }^{27}$ The first foundation is the Constitutional Foundation, which is the fundamental norm of national and State life, namely the Pancasila-based Law. The second foundation is the Operational Foundation, namely: 1) fair and prosperous law; 2) democracy strengthening law; 3) human rights protecting law; 4) Unity in diversitybased law (bhineka tunggal ika); and 5) Indonesia nations and country protecting laws. The fundamental foundation becomes the basis in the implementation of national legal politics because legal politics determines the direction of the overall national development policy to implement in a certain period.

Before the COVID-19 pandemic, globalization was one of the things that had a significant influence on legal politics. Globalization, as a lineage of advances science and technology, will bring up new risks and uncertainties that exceed anticipative abilities. This enormous change has revolutionized tradition and even religion, which has been the basis of many people. It does not stop there; the process transforms values in the family and also the State. ${ }^{28}$ In addition to globalization, one thing that was rife and felt urgent was the presence of the industrial era 4.0. One of the biggest things in the Industrial Revolution 4.0 is the Internet of Things (IOT), the ability to connect and facilitate the communication process between machines, devices, sensors, and people through the internet network. ${ }^{29}$

Like globalization and the industrial era 4.0, the COVID-19 pandemic can also affect the politics of Law in Indonesia, for example, in the politics of Law and regulations. The Government is required to respond quickly to the impacts arising from the COVID-19 pandemic, including several policies without ignoring the stages

26 Look paragraph 4 Pembukaan Undang-Undang Dasar Negara Republik Indonesia 1945.

27 National Legal Planning Centre (Pusat Perencanaan Pembangunan Hukum Nasional). 2012. Perencanaan Pembangunan Hukum Nasional 2015 - 2019, Jakarta: Badan Pembinaan Hukum Nasional. page 56.

28 Antony Giddens.. Runway World, How Globalization Is Reshaping Our Lives.( Jakarta: Gramedia, 2001). page 54.

29 Accessed from https://binus.ac.id/knowledge/2019/05/mengenal-lebih-jauh-revolusi-industri-4-0/, 2 June 2020. 
of regulation formulation. How the policies compiled remain of high quality even if issued in a short time. In this regard, the legal product made must be following the objectives of laws and regulations formulation with the substance being adjusted to the conditions that existed at the time the laws and regulations were made. The State or Government is forced to make decisions that are not only quick but also careful, not only about wealth but also about health.

It should be understood that the concept of The New Normal or New Normality, which is about to be applied in Indonesia, is not only done with a consideration of the economic approach. Realizing the State's goal as a welfare state as mandated in the constitution is also essential. There are 3 (three) indicators in improving public welfare, namely good health, good economy, and good education; ${ }^{30}$ therefore, it fits for legal politics in the concept of The New Normal to prioritize this principle. The 1945 Constitution of the Republic of Indonesia as the source of all national legal politics must remain a foothold by making Pancasila the basis of the State.

The Government strategy against the COVID-19 pandemic is that the Government should be able to produce a way out policies. The Government, through its power, must be able to provide answers to problems and accommodate the public interest through policies that not only stop until the domain of the policy is issued but how these policies can be implemented and sustainable to achieve the State's goals. Until the phase of tested legal compliance and awareness, as a sustainable system, the legal culture is at the same time part of an effort to accelerate the eradication of the COVID-19 pandemic.

Legal awareness is one of the critical elements in addition to the element of legal observance, which determines whether effective or not the implementation of the Law or legislation in society. According to Krabbe, legal awareness is an awareness or values found in human beings, about existing laws or expected laws exist. ${ }^{31}$

Legal awareness has several conceptions, one of which is the conception of legal culture. This conception contains the teachings of legal awareness, which is more concerned with legal awareness, which is considered as a mediator between Law and human behavior, both individually and collectively. ${ }^{32}$

According to Achmad Ali, there are two types of legal awareness, namely: ${ }^{33}$
a. Positive legal awareness is synony- mous with legal observance.
b. Negative legal awareness is synony-

\footnotetext{
30 Accessed from https://nasional.kompas.com/read/2020/05/31/06381421/mahfud-md-klaim-new-normaltak-diterapkan-dengan-pendekatan-ekonomi-semata, 3 June 2020.

31 Theory of Legal Awareness (Teori Tentang Kesadaran Hukum) Accessed from http://ruslanmustari.blogspot. com/2017/09/teori-tentang-kesadaran-hukum.html?m=1 3 june 2020.

32 ibid

33 ibid

34 ibid
} 
mous with legal disobedience.

The indicators of legal awareness, according to Soerjono Soekanto, are as follows: ${ }^{34}$

a. Legal knowledge means one knowing that Law has regulated certain behaviors. The legal regulations referred to here are written and unwritten laws. The behavior refers to behavior that is prohibited or pemitted by Law.

b. Understanding the Law means one who has knowledge and understanding of certain rules; for example, a student having knowledge and correct understanding on the nature and importance of school rules.

c. Legal attitude means one tends to make certain judgments towards the Law.

d. Legal behavior means one or student complying applicable regulations.

The four indicators of legal awareness mentioned above may indicate specific levels of legal awareness in the practice . If a person only knows the law, it shows that he has a low level of legal awareness, but if he behaves in accordance with the law in a society, it displays his high level of legal awareness.

Therefore, legal awareness is none other than the views that live in society about what law is. Views of life in society are not solely a product of reasoning considerations but they are developed under the influence of several factors such as religion, economics, politics, and so on. ${ }^{35}$

The concept of New Normal will lead to the following impacts: ${ }^{36}$

a. Clean lifestyle.

Handwashing habit, consuming nutritious food, and drinking lots of water can prevent various diseases. It also affects the life expectancy of the people in this era. Because practicing a clean and healthy lifestyle will support immunity system to make it less vulnerable to illnesses and greater longevity.

b. Orderly lifestyle.

New Normal will force people to adopt a stay at home lifestyle. In the end, mobility will decrease dramatically, and people will also be required to always wear masks when traveling outside the home. Shopping for daily necessities will depend on mobil application or online. People will also be more selective in shopping (needs vs. wants).

c. Natural lifestyle.

Activities will be more centered at home. The public will also tend to return to traditional ingredients or herbs to maintain body health. Simple activities such as washing hands and basking in the sun will be preferable activities.

35 Accessed from http://zriefmaronie.blogspot.com/ 2014/05/ kesadaran-kepatuhan-hukum.html? $\mathrm{m}=1 \#:$ :text=Kesadaran $\% 20$ hukum $\% 20$ erat $\% 20$ kaitannya $\% 20$ dengan,berarti $\% 20$ menanamkan $\% 20$ nilai\%2Dnilai\%20kebudayaan, Kesadaran \& Kepatuhan Hukum 3 june 2020.

36 Accessed from https://uai.ac.id/ada-apa-dengan-new-normal/diunduh 3 june 2020. 
d. Era 4.0. lifestyle

Virtual optimization that rules working from home to school from home will greatly utilize technology. This lifestyle is expected to give birth to a generation of virtual meetings. As a matter of fact, health consultations will also use technology by relying on telemedicine services.

e. Social Solidarity lifestyle

The emergence of togetherness and a sense of unity, testing the humanity and togetherness and will be more meaningful amid the COVID-19 pandemic as it is now.

New Normal Life is undoubtedly based on the awareness of the community that the coronavirus will always be around as any other viruses. Inevitably, we all have to adapt to a new lifestyle in the future that is to implement the health protocols in daily life activities. Bustami, a Sociology Observer, said that the condition called New Normal naturally forms when a prolonged condition, namely the exposure of COVID-19, was exceeded optimally. ${ }^{37}$

New Normal will be established through new habits in society as a result of 'habitual learning' that has been done for a long time, usually for years, so that they become a habit and then embedding to the attitudes and behavior of individuals in that society. President Jokowi also asked the public to continue to improve discipline in implementing the health protocols before entering a new normal lifestyle during this pandemic.

\section{Closing}

In national law, the enactment of Presidential Decree Number 11 of 2020 on Declaration of Pulbic Health Emergency of COVID-19 signifies the pandemic status of the Corona Virus Disease 2019 (COVID-19) in Indonesia, which is further strengthened by Presidential Decree Number 12 of 2020 concerning Determination of NonNatural Disaster Spread of Corona Virus Disease 2019 (COVID-19) as a National Disaster. Therefore, it can be categorized as a cause of force majeure under any contracts in general. It is then followed with the Government Regulation in Lieu of Law Number 1 of 2020 Regarding State Financial Policy and Financial System Stability for Handling Corona Virus Disease 2019 (COVID-19) and/or in order to Manage Threats Harming National Economy and/or Stability of Financial system. And the latest Government policy by suggesting people to make peace with COVID-19 by echoing what is called the New Normal or new lifestyle, which cannot be separated from the efforts that have been made by the Government inso far in dealing with the spread of COVID-19. The implementation of the health protocols and restrictions on community movements carried out by the Government have direct impacts on the community, including on the public service sector providing direct services to the public, health services at various levels of health facilities, lease services in the banking services sector and others.

37 Accessed from http://ubb.ac.id/2020/05/27/pengamat-sosiologi-penerapan-new-normal-vs-old-normal-terkait-situasi-COVID-19, 3 june 2020. 
The practice of state administration is increasingly being carried out in the executive, legislative, and judiciary environments by utilizing digital networks through application facilities that provide virtual meeting services. The cabinet meeting held by the President and the ministers since the COVID-19 outbreak always used digital facilities. This situation is also the case for the DPR. Despite having an extended recess period of up to a week, the DPR finally held a plenary meeting opening at the end of March. Meetings followed the agenda by the council's equipment (AKD) by combining physical and virtual meetings. Of course, the quorum conditions which under normal circumstances become an absolute requirement, in a situation like this is changing. The same thing is done in a judicial institution. Through the Supreme Court Circular No. 1 of 2020, it is encouraging justice seekers in the matters of trial administration by utilizing e-court applications and relating to the conduct of trials using e-litigation, especially for civil, religious and State administrative matters (TUN). COVID-19 has made the branches of state power metamorphosed to be adaptive to digital. This situation, whether realizing or not, has changed the way of having a disruptive perspective.

In its implementation, regulations related to Large-Scale Social Restrictions (PSBB) are still overlapping and even counterproductive. The existence of regulations that are not in harmony, causing legal uncertainty for the community, and also for government officials from the lowest level to control and educate the public in the application of existing regulations. Legal observance cannot be realized if it is not clear which rules must be obeyed. The legislation is an important element in the rule of law to carry out efforts to achieve national goals. Ineffective regulations will have a negative influence on the rule of law. In this regard, the effectiveness of a Regulatory Agency/Agency is needed in regulating and simplifying regulations and legislation so as not to ensnare and slow down the Government's move to take policies.

COVID-19 pandemic has the same impact as globalization and the industrial era 4.0. COVID-19 pandemic can also influence public legal awareness, such as clean lifestyle, orderly lifestyle, natural lifestyle, 4.0 era lifestyle, and social solidarity pattern. New Normal Life is undoubtedly based on people's awareness that the coronavirus will always be there like other viruses. Inevitably, we all have to adapt, the new lifestyle going forward is implementing health protocols in daily life activities.

\section{Bibliography}

1. Allots, Anthony. The Limits of Law, (London: Butterworths, 1980).

2. Banakar, Reza dan Max Travers (ed.),

95 Muhammad Akib, Hukum Lingkungan Perpspektif Global dan Nasional (Environmental Law: Global and National Perspectives) (Jakarta: Rajawali Pers, 2014) p. 40.

96 Ray Hilborn and Michael Melnychuk, loc.cit., p. 11. 
An Introduction to Law and Social Theory, Oxford: Hart Publishing.

3. Cruz, Peter de. Comparative Law in a Changing World ( $2^{\text {nd }}$ ed.)., London: Cavendish publishing Limited, 1999).

4. Deflem, Mathieu (ed.)., Habermas Modernity and Law, (London: Sage Publications, 1996).

5. Dworkin, Ronald. Legal Research, (Daedalus: Spring,1973)

6. Giddens, Antony. Runway World, How Globalization Is Reshaping Our Lives. (Jakarta: Gramedia. 2001)

7. Habbermas, Jurgen. Between Facts and Norms, (Cambridge: Polity Press, 2006).

8. Indrajit, Richardus Eko. Information Systems and Information Technology. (Jakarta: Elex Media Komputindo, Gramedia, 2000).

9. Indrakusuma, Amir Daien. Introduction to Education Science (Malang: Fakultas IImu Pendidikan IKIP, 1973).

10. Ihsan, Fuad. Education Basics, Cet. II. (Jakarta: Rineka Cipta, 2001).

11. Kusumaatmadja, Mochtar. Law, Society, and National Law Enforcement, (Bandung: Binacipta, 1976).

12. Mahfud, Choirul. Multicultural Education, (Yogyakarta: Pustaka Pelajar, 2006).

13. Mahayana, Dimitri. Fetching the Future, (Futuristic And Engineering Society Towards a Global Era). (Bandung: Remaja Rosda Karya, 1999).

14. MD, Mahfud. Building Legal Politics, Upholding the Constitution, (Jakarta: LP3ES, 2006).

15. Mudyahardjo, Redja. Philosophy of Education, An Introduction. (Bandung: Remaja Rosdakarya, 2001).

16. Rajagukguk,Erman. Dictate of Law and Development (discussion material for master program of law), (Jakarta: UI Pascasarjana, 2006).

17. Reksodiputro, Mardjono. Synchronizing Legal Renewal, (Jakarta:Komisi Hukum
Nasional, 2014).

18. Salman, Otje and Anton F. Susanto. Legal Theory: Remembering, Collecting and Reopening. (Bandung: Refika Aditama, 2004).

19. Soekanto, Soerjono and Sri Mamudji, Role and Use of Libraries in Legal Research, (Jakarta: Pusat Dokumentasi Hukum Fakultas Hukum Universitas Indonesia, 1979).

20. Wulandari, Liestiarini etall. National Law Development Documents, (Jakarta: BPHN, 2018).

21. https://www.Suara.Com., 02 June 2020

22. https://www.kompasiana.com/zakifahmi /5ecfea79d541df3e341380f2/simalakama-new-normal?page=all\#sectionall, 02 June 2020

23. https://idcloudhost.com/menelusuridampak-yang-ditimbulkan-psbb-di-seluruh-wilayah-indonesia, 2 June 2020

24. https://www.kiostix.com/id/article/503/ dampak-penerapan-psbb-dan-tujuanmulianya, 3 June 2020

25. https://www.kompasiana.com/hanafaih a/5eba5782097f3667e34daa62/psbbdampak-ekonomi-hingga-dampak-sosial

26. Https://www.tribunnews/com/corona/2020/05/26/pengertian-new-normaldan-protokol-pencegahan-penularabCOVID-19-di-tempat-kerja,. 02 June 2020

27. https://www.kompasiana.com/hpinstitut e/5ead17b5d541df3e62051864/ memahami-istilah-new-normal,. 02 June 2020

28. h t t p s : / / n e w s.de t i k. com / berita/d-5034719/tentang-new-normaldi-indonesia-arti-fakta-dan-kesiapandaerah, diakses pada tanggal 2 Juni 2020.

29. Https://www.tribunnews/com/corona/2020/05/26/pengertian-new-normaldan- protokol-pencegahan-penularabCOVID-19-di-tempat-kerja,. 02 June 2020 
30. w w w. I n s t a g r a m. c o m / p / CasGWejHW3b/?gshid=1 fnba8c5oavgrbicarapolitikhukum 1-6-2020

31. https://www.kompas.com/sains/ $\mathrm{read} / 2020 / 05 / 29 / 110000923 /$ new-normal-bukan-sekadar-membuka-ruangpublik-begini-kata-ahli 3 june 2020

32. https://www. TribunWow.com and Youtube KompasTV, 27 Mei 2020

33. https://www.liputan6.com/news/ read/4263884/ini-4-provinsi-dan-25-kabupatenkota-yang-akan-terapkan-newnormal

34. https://makassar.tribunnews.com/tag/ andi-anas-chaerul 2 June 2020

35. https://www.Kompas.com - 23/04/2020, 13:13 WIB

36. https://nasional.kompas.com/ $\mathrm{read} / 2020 / 04 / 23 / 13135641 /$ tantanganbertata-negara-di-tengah-disrupsi-sekaligus-era-pandemi-COVID-19.

37. https://www.bphn.go.id/data/documents/ fgd_dphn_prof._romli_a_konsep_reformasi_sistem_ hukum_ nasional.pdf, pada tanggal 2 Juni 2020.

38. https://mediaindonesia.com/read/ detail/305730-regulasi-tumpang-tindihdan bertentangan-persulit-penegakanhukum 1 June 2020.

39. https://www.kompas.tv/article/80195/ ada-tumpang-tindih-aturan-pemerintahsaat-pandemi-corona 2 June 2020.

40. https://setneg.go.id/baca/index/pemerintah_evaluasi_pelaksanaan_psbb_secara_menyeluruh 2 June 2020.

41. https://www.setneg.go.id/ baca/index/ menata_regulasi_di_pusat_dan_daerah _demi_kecepatan_merespons_perubahan 3 June 2020.

42. https://binus.ac.id/knowledge/2019/05/ mengenal-lebih-jauh-revolusi-industri-4-0/,2 June 2020.

43. https://nasional.kompas.com/ $\mathrm{read} / 2020 / 05 / 31 / 06381421 / \mathrm{mahfud}$ md-klaim-new-normal-tak-diterapkan- dengan-pendekatan-ekonomi-semata, 3 June 2020.

44. http://ruslanmustari.blogspot. com/2017/09/teori-tentang-kesadaranhukum.html?m=1 3 june 2020

45. http://zriefmaronie.blogs pot. com/2014/05/kesadaran-kepatuhan-hukum.html? m=1\#: :text=Kesadaran $\% 20$ hukum $\% 20$ erat $\% 20$ kaitannya $\% 20$ dengan, berarti\%20menanamkan $\% 20$ nilai\%2Dnilai\%20kebudayaan, Kesadaran \& Kepatuhan Hukum 3 june 2020

46. https://uai.ac.id/ada-apa-dengan-newnormal/diunduh 3 june 2020

47. http://ubb.ac.id/2020/05/27/pengamatsosiologi-penerapan-new-normal-vsold-normal-terkait-situasi-COVID-19, 3 june 2020.

48. Law No. 24 of 2007 on Disaster Management

49. Law No. 25 of 2009 on Public Services

50. Law No.12 of 2011 concerning the Formation of Regulations and Regulations

51. Law No. 15 of 2019 concerning Amendments to Law No.12 of 2011 concerning the Formation of Regulations and Regulations

52. Law No. 6 of 2018 on Health Care.

53. Government Regulation No. 21 of 2020 concerning Large-Scale Social Restrictions (PSBB)

54. Presidential Decree No. 1 of 2020 on State Financial Policy and Financial System Stability for Handling the COVID Pandemic-2019,

55. Presidential Decree No. 11 of 2020 concerning Community Health Emergency

56. Minister of Health of the Republic of Indonesia Number 9 of 2020 Regarding the Guidelines for Large-Scale Social Limits in the Context of Handling Corona Virus Disease 2019 (COVID-19)

57. DKI Governor Regulation No. 33 of 2020 concerning Implementation of PSBB for Prevention of COVID-19 Transmission in Jakarta 


\section{Curriculum Vitae of the Author}

Prof. Dr. H. R. Benny Riyanto, S.H., M. Hum., C.N. is a Head of National Law Development Agency - Ministry of Law and Human Rights of Republic Indonesia, whose also serves as a Professor in Law for Faculty of Law of the University of Diponegoro. His expertise in Civil Procedure Law reflected on the books published, among others "Kebebasan Hakim", "Mengenal Alternative Dispute Resolution", "Hukum Acara Perdata Permulaan Proses di Pengadilan", "Mediasi sebagai Sarana Penyelesaian Sengketa Bisnis" and "Hukum Acara Perdata di Indonesia".

Besides writing books, he also actively write several international manuscripts and journals such as IOP Conference Series: Earth and Environmental Science, "The Role of Notary Public Honorary Council in The Enforcement of Notary Code of Ethics in Indonesia," Q3, 2018. Humanities \& Social Science Reviews, "Reformulation of Mediation in Dispute Settlement on Islamic Banking," Q2, Vol 7, No. 4, 2019. International Journal of Scientific \& Technology Research, "Application of Notary Responsibilities in Civil Arrangement of the Position of Notary and the Principle of Civil Alliance," Q2, Volume 9, Issue 01, January 2020. The International Journal of Innovation, Creativity, and Change, "Assessing the Concept of a Civil Partnership of Notary in Indonesia," Q2, September 2020. 